\title{
ZNF444 wt Allele
}

National Cancer Institute

\section{Source}

National Cancer Institute. ZNF444 wt Allele. NCI Thesaurus. Code C106359.

Human ZNF444 wild-type allele is located in the vicinity of 19q13.43 and is approximately $28 \mathrm{~kb}$ in length. This allele, which encodes zinc finger protein 444 , plays a role in transcriptional activation, DNA binding and LDL metabolism. 